\title{
SHOCK IN THE OTORHINOLARYNGOLOGICAL OPERATIONS
}

(STATISTICAL OBSERVATION OF THE SURGICAL SHOCK)

\author{
By \\ YASUNobu SUZUKI, MinoRU IIDA, Kenjirou TAMAGAWA \\ Töru NAKAGAWA AND Hideo AMAYA
}

From the Department of Oto-Rhino-Laryngology School of Medicine, Keio University

(Director: Prof. Y. SUZUKI)

The results of 116 cases of the shock in the Otorhinolaryngological field observed in 58 large hospitals of Japan, were studied statistically and the following conclusions were obtained.

(1) Most of the shock in the Otorhinolaryngological field were related to the administration of local anesthetics befor operation and most of them appeared within $5 \mathrm{~min}$. after administration of local anesthetics.

(2) Death rate of the shock was less in the nasal manipulation than in other Otorhinolaryngological regions.

(3) Shock cases were classified into 5 types on the basis of clinical findings;

Type I Severe case (Convulsion Form)

Light case (Shibire Form) $=$ Type $\mathrm{V}$

Extremcly (Numbness)

Type II Rapid Syncope Form

Type III Pale Syncope Furm
Type IV Respiratory Syncope Form

Convulsion-form (Type I) was seen most frequently in our clinics and showed high fatality, so clinically it is the most fearful type of the shock. On the contrary numbness form (Type V) is the least dangerous of all.

(4) Some correlation between age and shock type was found. That is, convulsion form was often seen in the case of children under 10 years old and numbness form was often seen in the one and two decades. In the age over 50 years old, pale syncope form and respiratory syncope form were more frequently found.

(5) The different types of local anesthetics had no counection with the shock types.

(6) Abnormal diathesis (e.g. allergic diathesis) was found to be the chief disposition of the shock and should be thoroughly checked before administration of anesthetics.

\section{耳鼻咽喉科手術とショツク}

\section{一特に手術に関連したショックの統計的観察 一}

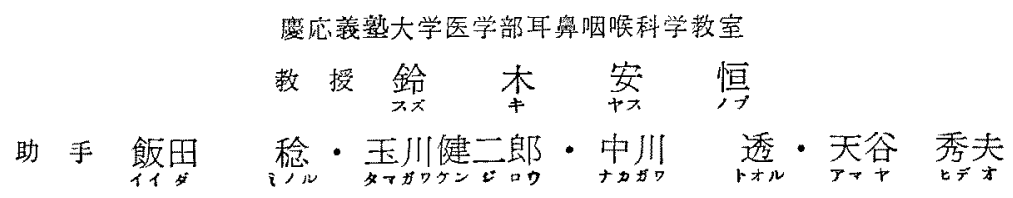

\section{Iはしがき}

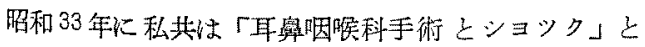
いら諭文を雑誌「耳掳咽堠科り」に発表しましたが，症 例数も少なく蔇念的な絬論しかでききせんでしたので，
その後全玉の235 の大学病院及び官公私立大病院に耳留

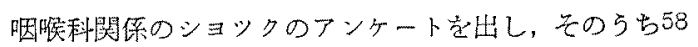
の病院から御回答を得，このたびそのデーターがましま り亲したので御趣告申上げます 
第 1 図ショック症例アンケート用紙

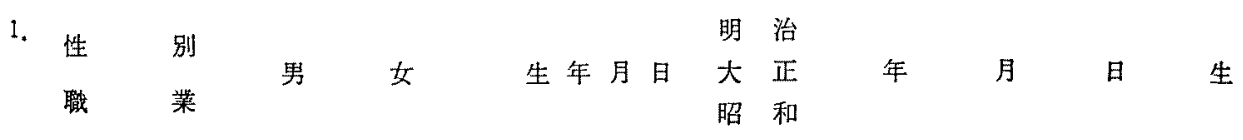

2. ショックの発生した日時

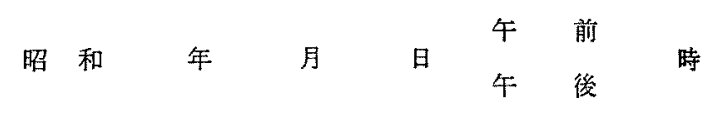

3. ショツク発生時の手橿名（㕛は処置名）

扁桃摘出術履杫周囲膿瘍切開術口蓋破裂成形術

小耳症拉よび外耳道閉鎖症手術副粤腔手術その他

4. ショツクの発生迄にどんな薬品が，いかなる手方法で投与されましたか。
藻 品名
投与 法

a.

b.

c.

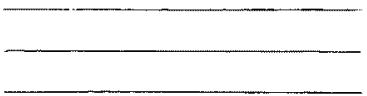

5. ショツク症状が発現する迄に，手街はどの硅度まで嫁行されていましたか。
a, 衙 前 処 置
b. 手㲚中
c.手術䅂了後

(できれば詳細に)

6. 手術(又は処䞉，注射）を開始してからショック発現までの時間。

7. ショック状態持続時間

8. 定 状

A. 初発症状

B. 鮕床症状

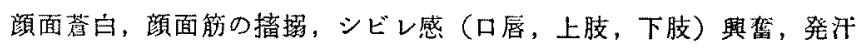

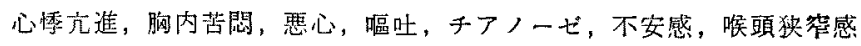

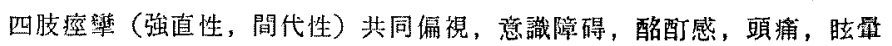

C. 貙木所見

血旺脈搏蹱孔

呼吸眼球連動 反射他

9. 主な治療法

10. 枟候 時間後に死亡 時間後に回隼

11. 何がショックの妵接の原因であつたと考点られますか。

12. 悲园の有無

アレルギー体貿 奇型 内分泌疾患 神経采疾患 代謝疾患
心血管柔珻患 その他—

13. 主な既往矣患

14. 剖娭所見 
II 年令, 性別, ショック発生年月日

フンケートの内容は、第1図のよらな形式でおこない 李した. 集まりましたショック症例は棇計116例でうら 男子65例，女子51例であります その年令構成は第 2 図 のようであります。すなわち10〜20才，20〜30才が艺 れそれ全例の約 $1 / 4$ を占めてもつとも多く，ついで 10

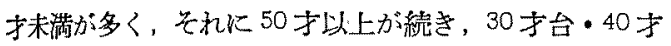
台がるつとも僅少であります しかし耳鼻咽啹科を訪れ る患者のららでは10才台, 20 才台のものがかなりの数 を占めておりますので必ずしも10才台，20 才台がショ ックを起す比率が高いとは申电せせん，乙かし東京監察 四務院の麻醉死の統計では20〜24 寸をピークとしてそ れ以下のいわ㠴る内分泌不安定期に多いと記してありま †2).

ショック発生の年月日は，昭和 24 年より昭和 35 年迄

第 2 図

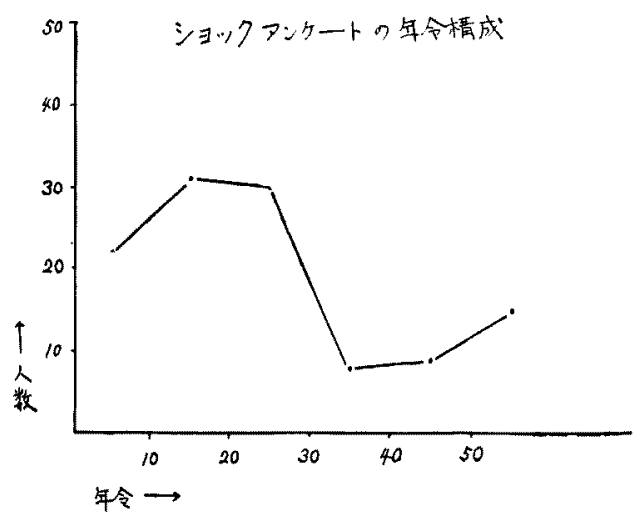

第 3 図

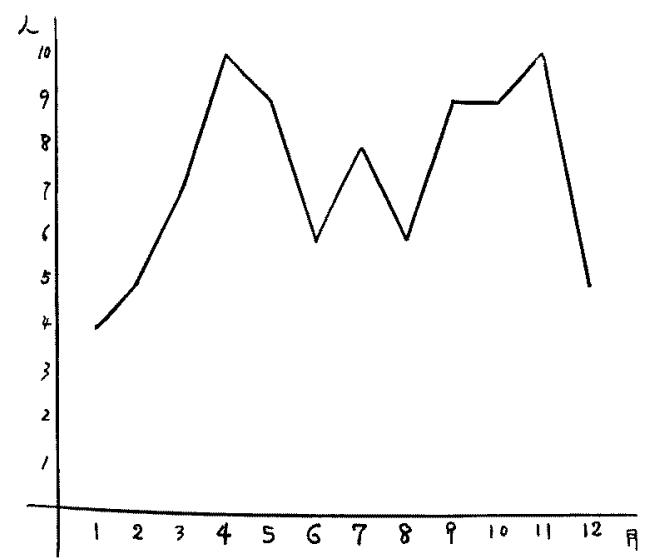

月别:
の症例が約 8 割を占めています、ショック発生の時期を 月別に分けますと第 3 图の上らになり市す。

\section{III 手術に関連したショック}

ショック発生の時に行わ机てい九手術あるいは操作を 種頪別にその主なものから順に例記しますと第]㤗のよ らになります。

第 1 表

\begin{tabular}{|c|c|c|}
\hline & & .38 \\
\hline 抗生物質使用 & " & $\ldots \ldots \ldots \ldots 15$ 例 \\
\hline 副鼠腔炎手術 & $"$ & …........... 8 例 \\
\hline 気管滇達鏡檢査 & $"$ & ...... 8 \\
\hline 㗹頭手䘗 & $"$ & .............6 6 例 \\
\hline 口蓋整形手術 & $"$ & ……..... 6 \\
\hline 中耳炎手術 & " & …….... 5 \\
\hline
\end{tabular}

（抗生物質によるるのはペニシリン10例，マイシリン 5 例上なつて扮ります)

第】表でわかります上らに手術に関連したショックが 先の大部分を占めて拈り亦すので本論文においては，手 術に関連したショックを中心として考察学進めたいと思 い来す

先バショック発生の時期を手術を中心として，手術 前，手術中，手術後之大別しますと第 4 図の如人術前 $53 \%$ ，術中 $32 \%$ ，術後 $15 \%$ の比率になります。

第 4 図

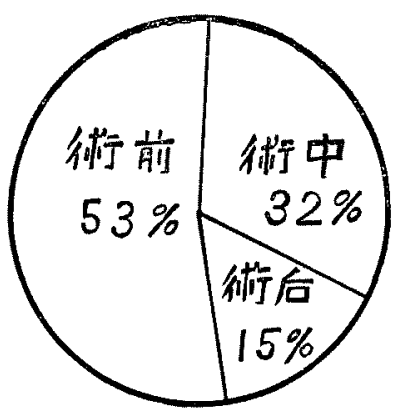

これによりますと術前の処置を行つただけで（例党ば 局䏫剂の注射など)手術学行う前にすでにショックを起 したものが約半数（53\%）を占めています 更に手術中 にショック起した症例について、ショック発生の時間的 傾向を調バますと, 執刀し始めてから5 分以内にショッ クを起しているものが約半数あります。これらは執刀直 


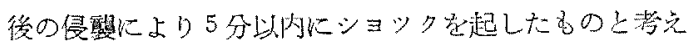

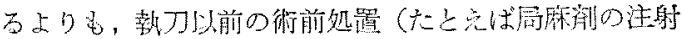

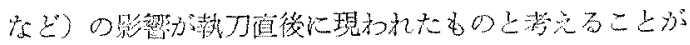

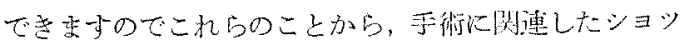

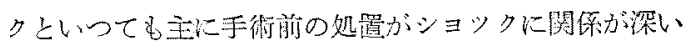

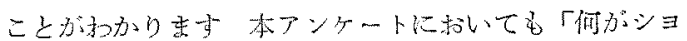

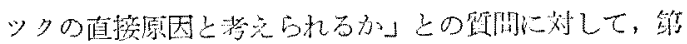

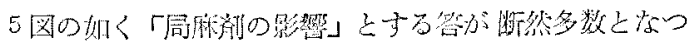

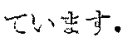

\section{第 5 图}

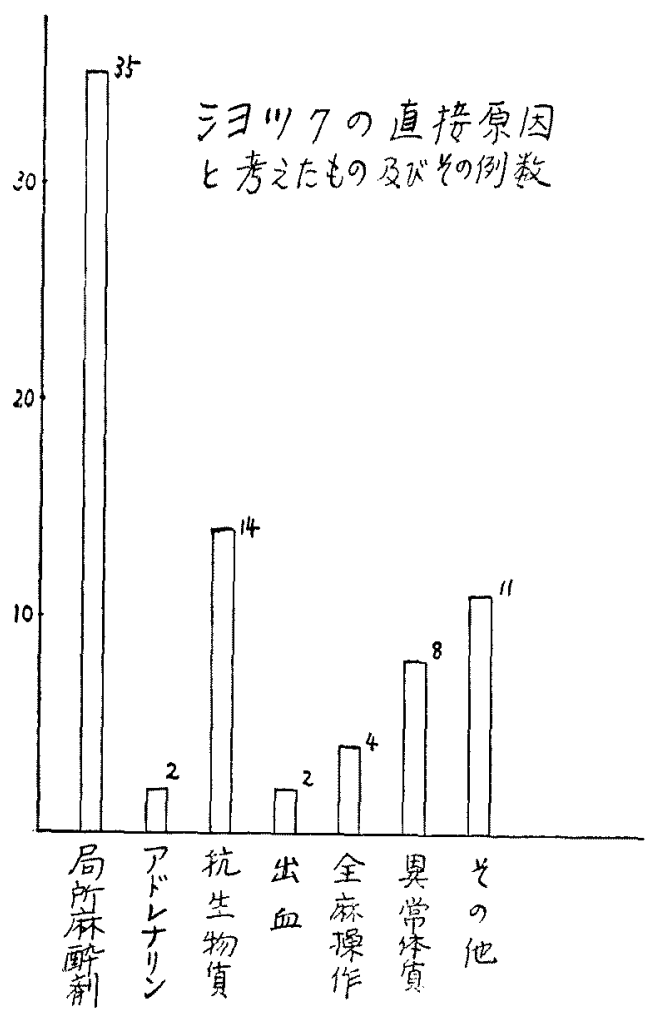

したがつて耳嶴㸶涘科関俰のショツクは手術前の処

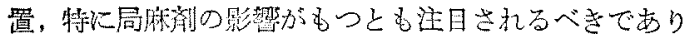
ます。

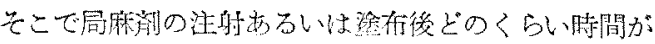

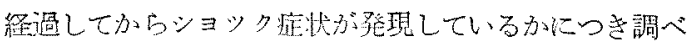

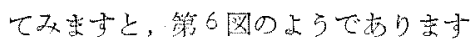

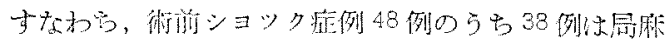

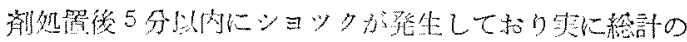

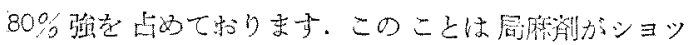

第 6 図局䏫剂学使用してからショックか゚ 始ま万迄の時間

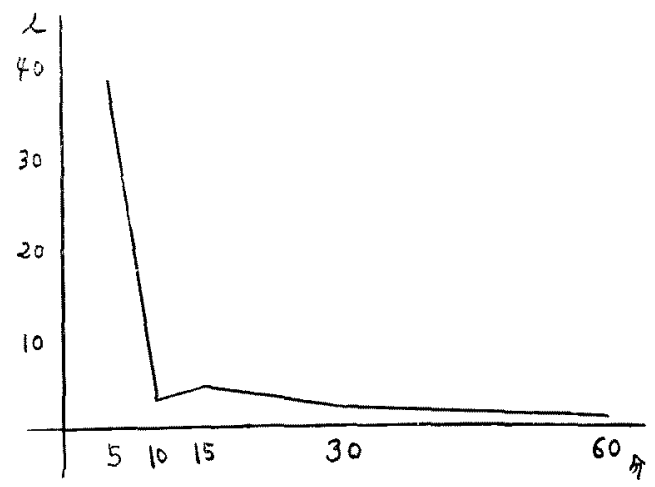

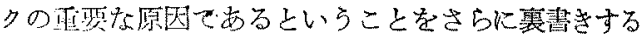

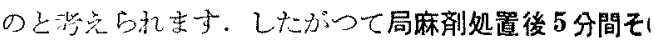
まっ篗察しその間にショツク症状が発現しなければ， いたいは術前ショックをまめがれたことになります。

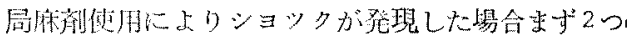

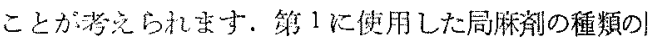

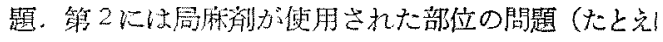

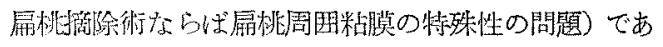

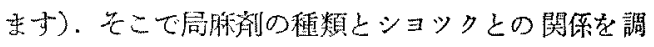
て东した。

\section{IV 局麻剂とショツクの関係}

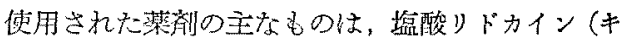
ロカイン), 塭酸プロカイン(ノボカイン), 塩酸シブ イン (ペルカミン文はペルカイン)テーカイン，塩酸 カインなどであります、症例中には上述の麻䣦削を2 類以上㑇用しているものがありますので（たとえばキ

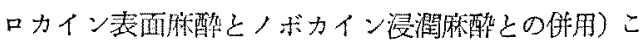
らの应例は除外し単独に1種類の薬剂たけを使用して

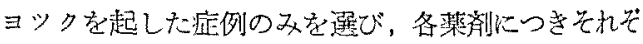
ショック登生数，ショック死亡数，致死率を算出して

第 2 表

\begin{tabular}{|c|c|c|c|}
\hline 繠 & 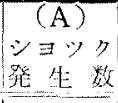 & 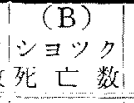 & $\frac{B}{A} \times 100=$ 致死 \\
\hline 壦酸りドカイン & 8 & 1 & $13 \%$ \\
\hline 捁賧プロカイン & 24 & 13 & 46 \\
\hline 塩酸ジブカイン & 14 & 8 & 57 \\
\hline テ $-\lambda 1 \nu$ & 5 & 4 & 80 \\
\hline 㩜酸コカイン & 2 & 2 & 100 \\
\hline
\end{tabular}


ますと第2表のようになります。致死率とはショックを 起した症例のうち何\%が死亡したかを現わしたものであ ります。

この表ては塩酸りドカインの致死率が特に少なく出て 和ります。しかしこれだけで各種麻醉削とショックとの 関係を諭ずることはははなはだ不十分でこのはが後 述の局麻剂の使用部位, 使用方法, 使用量, 䔉洞の灌度 なといろいろの因子が関保するのでこれらの諸条伴を加 味しなければ結論が出ないものと思和れますが一応参考 として記酨しました。

$\mathbf{v}$ 局麻剛の使用部位とショックとの関係

局麻削の使用部位を，耳，鼻，咽㬋頭に三大別しそれ 艺れについてショック発生数，死亡数，致死公を調べま すと第3表のようになります。これによりますと鼻では

\section{第 3 表}

\begin{tabular}{|c|c|c|c|}
\hline 部 位 & $\begin{array}{c}\text { (A) } \\
\text { 発生数 }\end{array}$ & 死亡 数 & 致死乘 $\frac{\mathrm{B}}{\mathrm{A}} \times 100$ \\
\hline 耳: & 11 & 5 & $46 \%$ \\
\hline 擧 & 17 & 3 & 18 \\
\hline 咽㗛気管 & 64 & 36 & 56 \\
\hline
\end{tabular}

その致死率がいらぢるしく低く出ています(ショック致 死率とは前述の如くショックを起した症例のうち何\%が 死亡しているかを表わしたものでショック発生率とは罢 ります).ショックのうちでも重症なものは注目されや すく，軽症なるのは見落さ机がちでいつぱんにアンケー 卜をとる時には軽症例は落されやすいものであります。 そこで実祭のショックの致死辢は括乞らく，はるが少

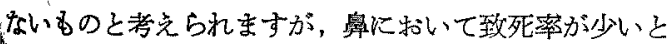
いらことは，われわれも踾床的に経験し感じていること で注目されてるよいと思います，鼻のばあい，なぜ致死 事が低いかこのことについては後で私見を述べたいと思 います。

\section{VI ショックの症状について}

ショックの際の症状につき検討致しますと

(1) 初発症状䛃化

これは初発症状といらよりまず最初に気付いた症状上 いらべきものですが，これを頻度の多い症状上り順に亚 ペてみますと第4表のようになります。

(2) 型分類

ショックの型分類については従来いるいるの分類がな されて放りますか，私等はフランスのミッシェル・ポル

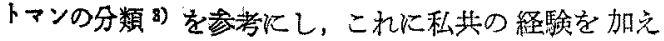

第 4 表

\begin{tabular}{|c|c|}
\hline 初発症状 & 初発症状 \\
\hline 面 藘 白…..18 & 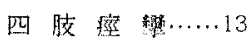 \\
\hline 内笘 & 心..... 9 \\
\hline 苦 ᄂ w.....? 7 & 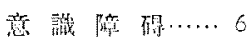 \\
\hline$T /-t+\ldots . .5$ & 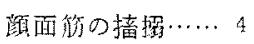 \\
\hline ビ レ 感…...5 5 & 脈㨨 勫 小……3 \\
\hline 廂……2 2 & 血 厓低 下…… \\
\hline 面 軓 赤……2 2 & 呼罗侼止…… \\
\hline 身 発 赤……2 & \\
\hline
\end{tabular}

第 5 表

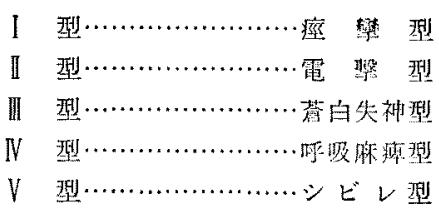

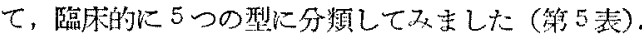
各型の臨床症状は次の上うで招ります。

I 型 (痓繁型)

始めに漠然とした前兆があり，顔面荅白になら，時に

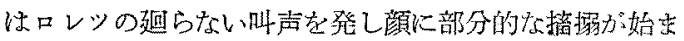

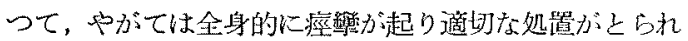
なければ座戀が頻発し，急速に心臹性 (Syncope cardi-

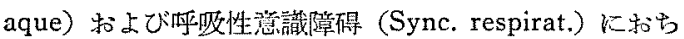
いり短時間で死亡する予後の覀い型で方り，古くから記

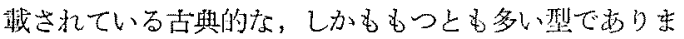
す

\section{II 型 (電慗型)}

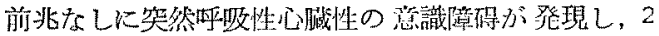
〜3 回呼吸すると見る間に死亡する急性型で坚にして頻 度は少ない样です。

III 型 (鹤白失神型)

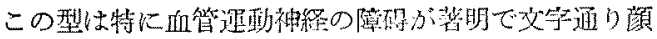
面荅白となり，血壬低下，脈搏頻数微弱となり失神:状態 に陌る型でこの型も時には死の轾帰をとりまず。

IV 型 (呼-吸麻埤型)

重篤なチアノーゼを伴つた完全な呼吸運怔停止，散獞 を併つたひどい牱吸性意諳障碍をきたし酸㨞吸入により 速か炕患者を蔡生させ得るがこれを止好る上再びチア，

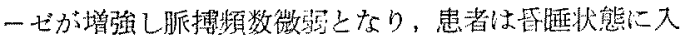

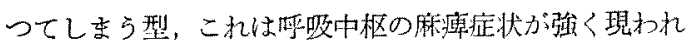
た型であります。 
$V$ 型 (シビレ型)

この型はシビレ感を主幑とし，胸内苦焽，顔面蓄白，

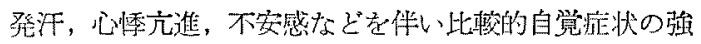

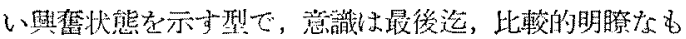
のが多いようですこの型はI型（痤攀型）の軽症刑に

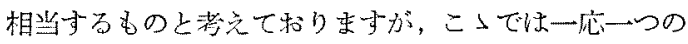

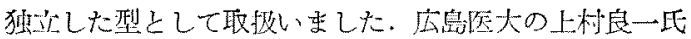

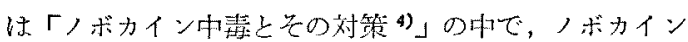

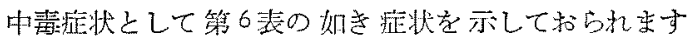
が，私共のV型がこの軽症にあたり皮質刺激反応が㾤䍃

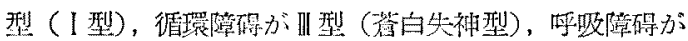

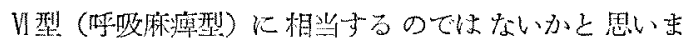
$+$

\section{第 6 表}

\begin{tabular}{|c|c|c|}
\hline 蒋 & \multicolumn{2}{|c|}{ 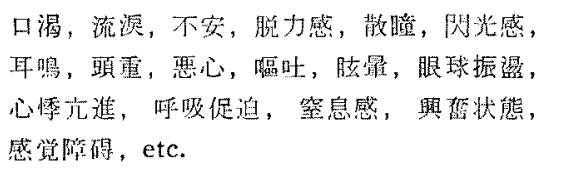 } \\
\hline 重 & 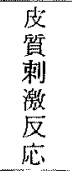 & 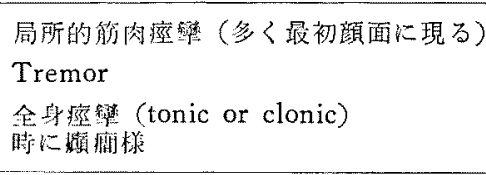 \\
\hline \multirow{2}{*}{ 症 } & $\begin{array}{l}\text { 偱隌 } \\
\text { 理碍 }\end{array}$ & 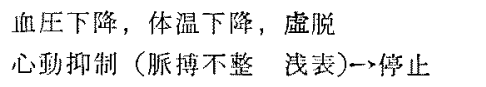 \\
\hline & $\begin{array}{l}\text { 呼陸 } \\
\text { 吸碍 }\end{array}$ & 呼吸抑制（㓪 \\
\hline
\end{tabular}

以上の如き分類はショックの定義から見て，かならず しもこれに談当しないものもあるかもしれませんが，臨

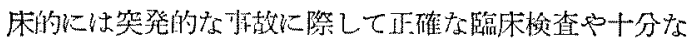
推察ができなかつた場合もありますので，あくまで臨床 的な見地から上のように分類したかけであります 奏際 にわれわれが推察与る倠例は上述したよらな定型的な型 ばかりてはなく，いくつかの型が混合したよらな怔状を 呈するものや，以上の分頪のどれに电該当しない上らな ものも多数見られますがだいたい以上のような分類で ショック症例をかけてみ走与と第子表のようになりま 于.

ショックの各型の発生顷度老第7表より見ますと, 痤

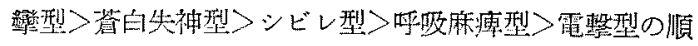
になり寺す痤繁型がもつとも多く全体の約半数 $(52 \%)$ を步めて和ります。

ポルトマンの分類においても痤熬型は $50 \%$ 強と記载
第 7 表

\begin{tabular}{|c|c|c|c|c|c|}
\hline 型 & & 例 数 & $\begin{array}{c}\text { 発生頻 } \\
(\%)\end{array}$ & 死 & 亡 数 \\
\hline I & 痤 塑速 型 & 49 & 52 & & 34 \\
\hline II & 電 愫 型 & 1 & 1 & & 1 \\
\hline III & 荅白失神型 & 20 & 21 & & 2 \\
\hline IV & 呼吸庶瘦型 & 6 & 6 & & 3 \\
\hline V & シビレ型 & 18 & 19 & & 0 \\
\hline & 計 & 94 & 100 & & 40 \\
\hline
\end{tabular}

されており、だたい私共の統計と同じ数值を示して和 ります.続いて四型 (荅白失神型)，V型 (シビレ型)， が多く，【型 (電揧型) が最字頻度が少ない上うであり ます また各型の悪性度を

各型の恥性度 $=\frac{\text { 各型の死亡数 }}{\text { 各型の発生数 }}$

の如く表わしますと以下のようになります

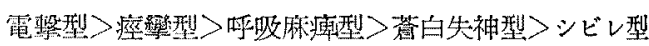

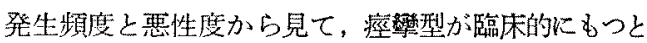
む恐るべき型であり，向つとる踷発する型であります。 シビレ型は軽症型でありますので発生頻度は割に多い が，覀性度の低い予後の上い型であります，蒼白失神型 と呼吸麻溥型はその中間に位し，電整型は悪性度は非常 に高いが発生数が非常に少ない点が注目されます。

以上の如く分類した型は拉そらく根本的には全然異つ た原因で発現したのではなく，外的刺激はだいたい同じ 種類のものであつてる，てれを受ける生体側の反応態度 によつて，異なつた症状を呈主るものと思和れすす，従 つて臨床症状によつて各型に判然と区別することはむし ろ不可能で，どららの型とるとれるような症状を呈する 症例が多いのは当然のこと入思われ亦す。しかし大まか にでる分類することは去の予後を判定する上に役贴电 のと揟じすす

以上の如く分類した各型について，いるいるな触か ら檢䇣を行ないました。

i）ショックの各型と年令との関保について

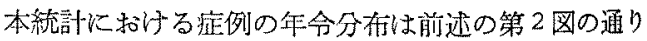
でありますが，こっではショック症例を各型别に分類 し，それぞれの型に属する症例の年令分布を調べますと 以下の图のよらになります（第7図）.

グラフは横軸に年令をとり，年令を10 年每に区切り， 10才末满，10才台，20才台などわけ，てれぞれの区” のショック例の度数を縦軸に表わしてあります グラフ 
第 7 図 1 型

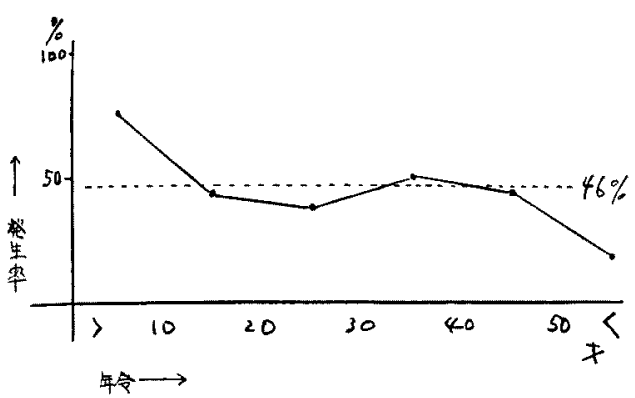

中央附近を横に水平に走る点楾（46\%と記載）はI型の 発生頻度を現わしていますが，これはとりもなをさずこ のグラフの平均值を示してい亦すこの平均值 $(46 \%$ )

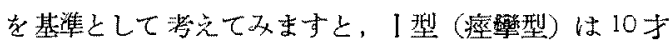
未满に多く，50才以上に少いといらことができます。

【型（電整型）と年令との関係怔症例が少いためにグ ラフにすることは省略しました。

秏型（會白失神型）では20才台を中心としてこれよ り若い世代炕は少く老いた世代では濑次增加するといら

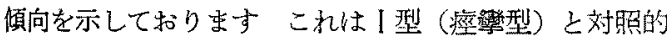
であります

\section{第 7 図 III 型}

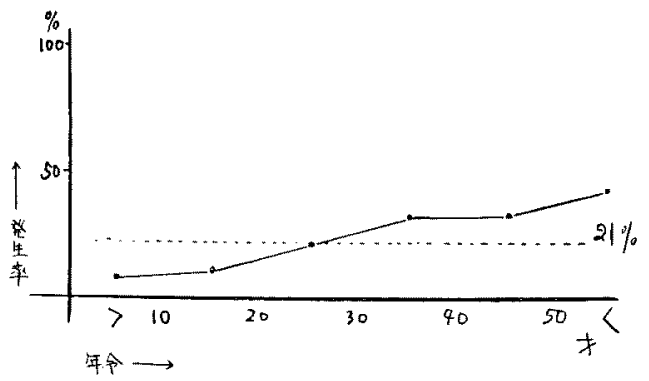

第 7 図 N 型

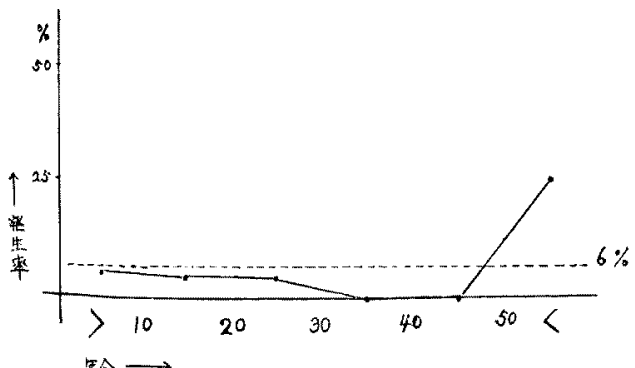

输 $\longrightarrow$
第 7 図 V 型

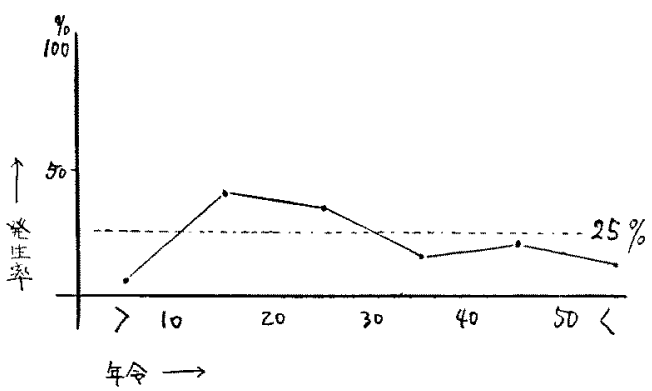

W 型（呼吸麻痺型）は図の如く50 寸以上に多い傾向 を示しております。

V型 (シビレ型) は10才台，20才台の若い世代に多 いと云う結果が出要した。

以上より年令とショックの型との間にはある程恰の関 連性があるように思われます

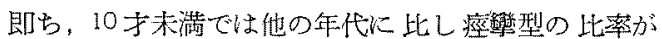
多く，10才台，20才台ではシビレ型の比率が多く50才

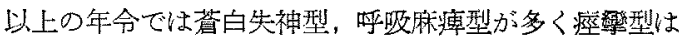
少いと云うことが云完ます。

このことは年令によつて刺激に対する植物神経系の反 応態度が異つている結果ではないかと考光られます

ii）ショックの各型と性別との関係について

男女別に各型の分布を調べましたが性別と各型の頻度 との間汇性特別の関係はみとめられません，

iii）侵䘫の加わつた部位とショックの各型との関倸に つい

耳とか鼻とかの手術の場合，その侵警の加わる場所が 異る時、ショック各型の発生度が異るかどらかと云ら問 題につき調べてみました，耳，鼻，咽喉頭気管に三大別 して，それぞれの区分に属するショック症例の型を調べ ますと，第8表のようになり。これをグラフにすると第 8图のようになります このグラフにより耳，鼻、咽喉 気管それぞれの部に批けるショック各型の発生比率をシ ヨック全症例に括けるショック各型の発生比率と比べて

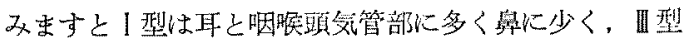
V型は各部共大差がなく，V型はI型とは逆に耳と咽㙃 頭気管部汇少く鼻化多いと云ら傾向てを示し扰ります I型は症例数が少いので省略しました。こつで前述の 「局䏫刘の使用部位とショックとの関保」の項の結論を 再び記しまずと耳及び咽喉頭気管部におけるシヨツク の致死率がそれぞれ46\%，96\%と高率であるのに詨して 
第 8 表

\begin{tabular}{|c|c|c|c|c|}
\hline 部位 & 型 & 例 & $\begin{array}{c}\text { 発生頻 度 } \\
(\%) \\
\end{array}$ & $\begin{array}{l}\text { 死亡 数 } \\
\text { (致死浮) }\end{array}$ \\
\hline \multirow{6}{*}{ 耳 } & I & 7 & 64 & \multirow{6}{*}{$\begin{array}{c}5 \\
(45 \%)\end{array}$} \\
\hline & $\mathbb{I}$ & 0 & 0 & \\
\hline & III & 3 & 27 & \\
\hline & IV & l & 9 & \\
\hline & $V$ & 0 & 0 & \\
\hline & 計 & 11 & & \\
\hline \multirow{7}{*}{ 舜 } & I & 4 & 25 & \multirow{7}{*}{$\begin{array}{c}3 \\
(18 \%)\end{array}$} \\
\hline & II & 0 & 0 & \\
\hline & III & 5 & 31 & \\
\hline & N & 1 & 6 & \\
\hline & $V$ & 6 & 38 & \\
\hline & 不明 & 1 & 6 & \\
\hline & 鼓 & 17 & & \\
\hline \multirow{2}{*}{ 吻 } & I & 37 & 62 & \multirow{7}{*}{$\begin{array}{l}36 \\
(56 \%)\end{array}$} \\
\hline & II & 1 & 1 & \\
\hline 㬋 & III & 9 & 15 & \\
\hline 頭 & IV & 4 & 7 & \\
\hline \multirow{3}{*}{$\begin{array}{l}\text { 要 } \\
\text { 管 }\end{array}$} & $V$ & 9 & & \\
\hline & 不明 & 4 & & \\
\hline & 計 & 64 & & \\
\hline
\end{tabular}

鼻では 18\%と低率を示すということであります。この

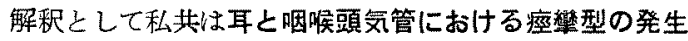
頻度は券の場合の病彎型の発生頻度にくらべて多く，逆 にシビレ型の発生頻度は鼻に多く耳及び咽喉頭気管部に 少いと云うデーターに注目したいと思います。

1 型山前述の如く臨床的には墨性度か゚高く死亡率の高 い型であり，V型は舆性度の低い軽拝型であります こでI型が多く発生する所では必然的に致死彎污增扣 し、V型が多い所では致死萃が低下します 従つて耳や 咽堠頭気管部の致死祭が鼠のそれに比して高率になるわ

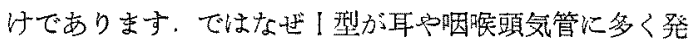

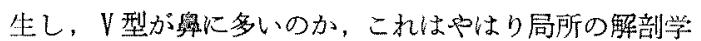

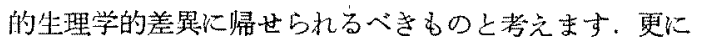
ショックの各型と年令との夙俰をおるい出して頂きすす と，10才未渵の幼弱なものに重症型である 型が多く 10 才，20才台つ若人に軽正型であるV型が多いと云う

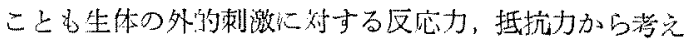
て，ある程华うなつけるのではないか上思います
第 8 図

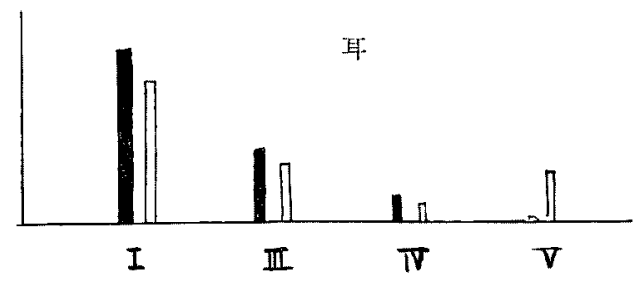

程

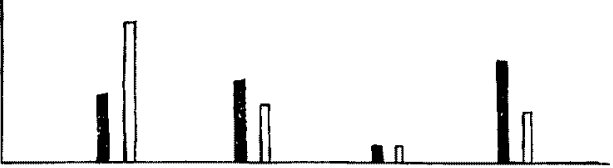

$\mathbf{I}$

吕 $\mathbb{V}$

V

咽喉無管

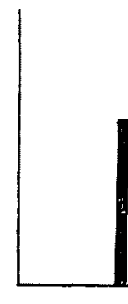

$I$

\section{III}

TV

$\nabla$

グラフ中左側の黑い棒グラフはそれぞれ耳・賁 ・㸶唤穴管に打ける各型のショツクの発生頻度 \%をあらわし，右側の白い棒グラフはショック 全症例に叔ける等のショックの発生頻度\%を あら放してい

第 9 表

\begin{tabular}{|c|c|c|c|c|c|c|}
\hline \multicolumn{2}{|c|}{ 型 } & 例 & 数 & 発生影度 $(\%)$ & & 亡 数 \\
\hline \multirow{2}{*}{1} & 孟 庭 & & 49 & 52 & & 34 \\
\hline & 軽 症 & & 18 & 19 & & 0 \\
\hline & $\rrbracket$ & & 1 & 1 & & 1 \\
\hline & III & & 20 & 21 & & 2 \\
\hline & IV & & 6 & 6 & & 3 \\
\hline
\end{tabular}

したがつて前述（第 7 表）のショックの分類は第 9 斌の ように㫪きあらためることができすす。

(V) ショックの各型と麻而薬の種類との関係沉い $\tau$ 
結諭的に申し上げあすと林斬削の種類とショックの型

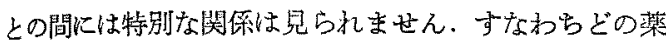
㑉はどの型のショックが多く発生すると云うことはない ように思われます

\section{VII 素因の問題}

本アンケートにより，素因の有無を調べたところ第 10 裴の如き結果を得京した。

\section{第 10 表}

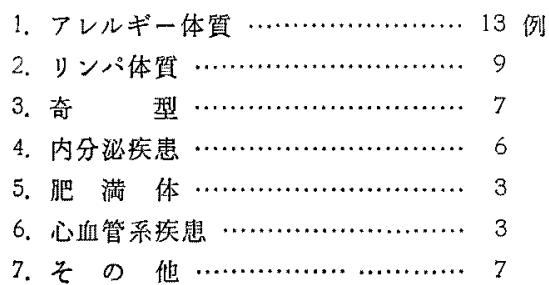

1と2はいわゆる異常体質に属するものであり3の奇 型は，7 例中 5 例が口盖破裂，1 例は外耳道閉鎖症，1 例は小耳症であります 文4と5は内分速疾患として 大きくまとあるとができると思います 子め手術の前 に以上の如き素因を問診あるいは検查してから手術に臨 むことがショック予防上重要なこと〉思われます

\section{VIII 緢 括}

○耳畺咽膲科関係のショツクにつきアンケートを中心と

して統計をとつてみました：泟例は総計 116 例で男65 例, 女51 例であります

○本統計によりますとショックの発生は手術に関連した

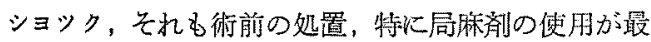
る影響があるように思放れます

○術前の処置炕よショックの大部分は処瑟後 5 分以内

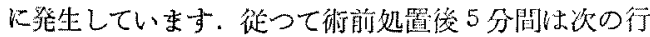
㽖に移ることなくそのま〉観察していることが望まし いと思います。

○局穈盛の使用部位とショックとの関係纪ついて，耳，

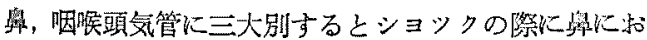
いて最も致死琼が少い。

○ショック定状を基にして5つの型に分類しました。す なから
I 型一重 症 型 (座擘型)
軽淀型 $($ シビレ型 $)=V$ 型
】型一電 整 型
II 型一鿓白失神型
N 型一呼吸森疾型

であります

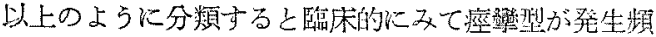
度も多くもつとも恐るべき型であり，シビレ型がいつ とも予後のよい型であります。

○年命とショックの各型との間にはある程度，関連性が

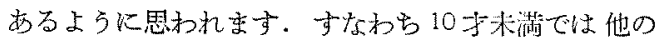

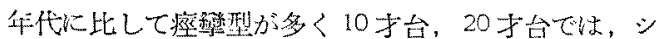
ビレ型の比率が多く50手以上では荅由失神型，呼吸

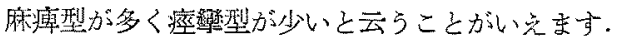

○ショックの各型と性別との間には特別な関例はみとめ られません。

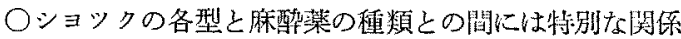
はみとめられません。

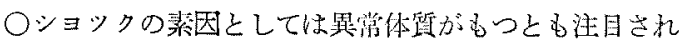
案与

\section{参考文献}

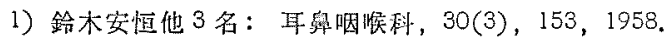

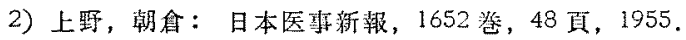

3) M. Portmann: D'Anesthésie et D'Analgésie

Tome XII Numéro, 4, p. 682, Sept 1955 . 4) 上 村良一：臨床外科，10(11):769，1955。(昭 30.11)

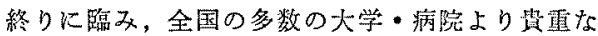
データーと激汤の御言葉を睗つたことに対して厚く 御礼申上げますこつにデーターを提供して下さつ た病院名を列記させて頂き深い感謝の湆を装しま 寸

$$
\text { データ一提做病院 }
$$

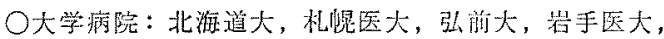

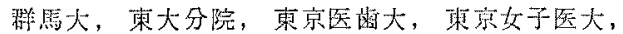

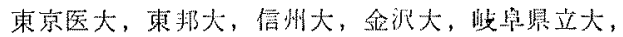

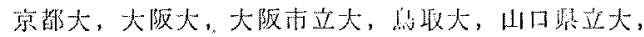

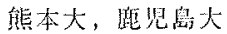

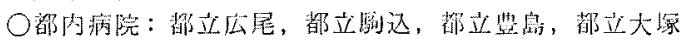

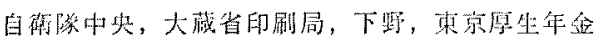

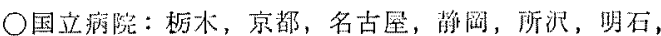
岩国, 褔山

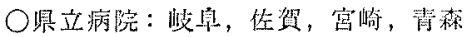

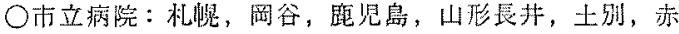
平, 江㓢, 臽馆, 小贏

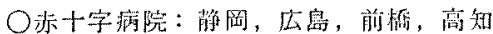

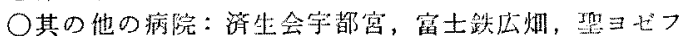
小倉記念，大阪厚生年金

(順不同)

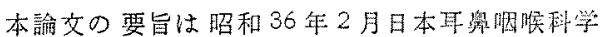
会閲東地方会 376 回例会に括いて䧼告致しました。

（原稳到算 $=$ 昭和 37.4.18日） 